\title{
Analisis Kesuburan Tambak di Bontang Kuala Kalimantan Timur
}

\author{
Henny Pagoray ${ }^{1}$ dan Deni Udayana ${ }^{2}$ \\ 1,2 Program Studi Budidaya Perairan Jurusan Budidaya Perairan Fakultas Perikanan \\ dan Ilmu Kelautan Universitas Mulawarman, Jl. Gunung Tabur Kampus Gunung \\ kelua, Samarinda, Kalimantan Timur \\ 1Email: pagoray.henny@gmail.com
}

\begin{abstract}
Ponds were one of the habitats that were used as a place for brackish water cultivation in coastal areas. The cultivation activities carried out have problems. One of the problems faced by farmers in Bontang Kuala today was a decline in production. The purpose of this study was to identify the conditions of ponds that are related to pond fertility, namely physically, chemically and biologically, and the analysis of soil quality. The research method was by analyzing of water quality in situ and ex situ. The parameters analyzed in situ were: temperature, $\mathrm{pH}$, dissolved oxygen, salinity; while the parameters analyzed in the laboratory are: TDS, $\mathrm{NO}_{3}, \mathrm{NO}_{2}$ and $\mathrm{NH}_{4}$, soil $\mathrm{pH}$, organic matter, N, P soil, whereas to see the plankton diversity was to take water samples for identification in the laboratory. The results of the analysis of water quality are compared with the environmental quality standards of East Kalimantan Province No. 339 of 1988 (Sea water quality standards for marine biota, aquaculture). Water quality physically and chemically was still in accordance with the standards for cultivation, whereas the soil organic matter was high and biologically the diversity of plankton was in medium category.
\end{abstract}

Keywords: water quality, pond fertility, bontang kuala

\section{ABSTRAK}

Tambak merupakan salah satu habitat yang dipergunakan sebagai tempat untuk kegiatan budidaya air payau di daerah pesisir. Kegiatan budidaya yang dilakukan mengalami masalah. Salah satu masalah yang dihadapi petambak di Bontang Kuala saat ini adalah penurunan produksi. Tujuan dari penelitian ini adalah mengindentifikasi kondisi tambak yang berhubungan dengan kesuburan tambak, yaitu secara fisik, kimia dan biologi, dan analisis kualitas tanah. Metode penelitian yaitu dengan menganisis kualitas air secara in situ dan exsitu. Parameter yang dianalisis secara in situ yaitu: suhu, $\mathrm{pH}$, oksigen terlarut, salinitas; sedangkan parameter yang dianalisis di laboratorium yaitu: TDS, $\mathrm{NO}_{3}, \mathrm{NO}_{2}$ dan $\mathrm{NH}_{4}, \mathrm{pH}$ tanah, bahan organik, $\mathrm{N}, \mathrm{P}$ tanah, sedangkan untuk melihat keanekaragaman plankton dilakukan pengambilan sampel air untuk indentifikasi di laboratorium. Hasil analisis kualitas air dibandingkan dengan baku mutu lingkungan Prov.Kaltim No.339 Tahun 1988 (Baku mutu air laut untuk biota laut, budidaya perikanan). Kualitas air secara fisik dan kimia masih sesuai dengan standar untuk budidaya, bahan organik tanah tinggi sedangkan secara biologi keanekaragan plankton termasuk dalam kategori sedang.

Kata kunci: kualitas air, kesuburan tambak, bontang kuala

\section{Pendahuluan}

Kegiatan budidaya merupakan suatu proses pemeliharaan untuk meningkatkan produksi, seperti penebaran yang teratur, pemberian pakan, perlindungan terhadap pemangsa (predator) dan pencegahan terhadap serangan penyakit. Kegiatan budidaya dapat dilakukan di tambak. Tambak merupakan salah satu jenis habitat yang dipergunakan sebagai tempat untuk kegiatan budidaya air payau yang berlokasi di daerah pesisir.

Masalah yang sering terjadinya adalah degradasi lingkungan pesisir akibat dari pengelolaan yang tidak benar. Penurunan mutu lingkungan pesisir akibatnya membawa dampak yang sangat serius terhadap produktivitas lahan bahkan sudah sampai pada 

produksi yang disebabkan oleh berbagai penyakit karena lingkungan sebagai habitat sudah tercemar oleh adanya buangan (limbah), tata letak tambak, jenis tanah setempat, kesalahan desain, dan teknologi pengelolaannya adalah faktor- faktor yang berperan terhadap penurunannya produktivitas tambak, (Hermanto, 2007).

Musa (2004), menyatakan bahwa kesuburan tambak sangat dipengaruhi oleh kualitas air (fisik, kimia, biologi) dan kesuburan tanah. Untuk mengetahui produktivas tambak tersebut maka perlu dilakukan suatu penelitian untuk mengidentifikasi kondisi tambak tersebut, dengan melihat faktor-faktor yang berpengaruh terhadap produktivitas tambak. Faktor yang berpengaruh terhadap kesuburan tambak yaitu kualitas air dan kualitas tanah. Tujuan penelitian adalah mengindentifikasi kondisi tambak yang berhubungan dengan produktivitas tambak, yaitu secara fisik, kimia dan biologi air serta analisis kualitas tanah.

\section{Metode Penelitian}

Lokasi pengambilan sampel di tambak Bontang Kuala, Kota Bontang Provinsi Kalimantan Timur. Pengambilan sampel dilakukan pada bulan Agustus tahun 2017. Parameter kualitas air, plankton dianalisis di laboratorium lingkungan akuakultur Fakultas Perikanan dan Ilmu Kelautan Unmul, dan parameter tanah di laboratorium tanah Fakultas Pertanian Universitas Mulawarman.

Penelitian yang dilaksanakan di tambak Bontang Kuala menggunakan alat: Thermometer, $\mathrm{pH}$ meter, DO meter, alat-alat untuk titrasi (pipet, gelas ukur), kamera, plankton net, water sampler, timbangan, botol flakon, freezer, kantong plastik, cold box, alat pemanas (hot plate). Bahan yang digunakan yaitu: $\mathrm{HNO}_{3}, \mathrm{HCL}, \mathrm{NaOH}$, standar nitrat, standar phosfat, standar nitrit, brucine sulfat, sulfanilic acid, lodium Natrium thiosulfat , KI, formalin.

Jenis data yang diperlukan dalam analisis produktivitas tambak yaitu dengan menganalisis sifat fisik, kimia dan biologi air dan juga pengamatan dilakukan terhadap kualitas tanah ( $\mathrm{pH}$, bahan organik, tekstur, $\mathrm{N}$ dan $\mathrm{P}$ total tanah).

Metode pengumpulan data yaitu dengan pengambilan sampel air dan tanah untuk di analisis laboratorium. Pengukuran kualitas air secara in situ dan ex situ. Parameter yang dianalisis secara in situ yaitu: suhu, $\mathrm{pH}$, oksigen terlarut, salinitas; sedangkan parameter yang dianalisis di laboratorium yaitu: TDS, $\mathrm{NO}_{3}, \mathrm{NO}_{2}, \mathrm{NH}_{3}$, Untuk tanah yang dianalisis yaitu: tekstur tanah, $\mathrm{pH}$, bahan organik ( $\mathrm{C}$ total), nutrisi tanah $\mathrm{N}$ total, $\mathrm{P}$ total, sedangkan untuk melihat keanekaragaman plankton dilakukan pengambilan sampel air kemudian di bawa ke laboratorium untuk diidentifikasi jenis plankton dan menganalisis indeks keanakaragaman, keseragaman dan dominansi plankton. 
Analisis data kualitas air dibandingkan dengan baku mutu lingkungan Prov.Kaltim No.339 Tahun 1988 (Baku mutu air laut untuk biota laut, budidaya perikanan). Analisis tanah berdasarkan kriteria sifat kimia tanah (Pusat Penelitian Tanah IPB, 1988). Dan untuk analisis indeks keanekaragaman plankton (Shannon Wiener) dengan rumus:

$$
\mathrm{H}=-\sum_{\mathrm{i}=1}^{\mathrm{n}}\left[\left(\frac{\mathrm{ni}}{\mathrm{N}}\right)\right] \ln \left[\left(\frac{\mathrm{ni}}{\mathrm{N}}\right)\right]
$$

Keterangan:

$\mathrm{H}=$ Indeks diversitas (keanekaragaman)

$\mathrm{Ni}=$ jumlah individu setiap jenis

$\mathrm{N}=$ jumlah total individu

\section{Hasil dan Pembahasan}

\section{Analisis Kualitas Air}

Hasil pengukuran kualitas air pada lokasi penelitian secara lengkap disajikan pada Tabel 1. Parameter kualitas air yang diukur terutama yang berkaitan dengan sifat fisikakimia air yang dapat memberikan gambaran kelayakan bagi kehidupan biota air, seperti suhu air, salinitas, TDS, pH, oksigen terlarut (DO), ammoniak (NH3-N) NO2 dan NO3.

Tabel 1. Hasil analisis kualitas air pertambakan di Bontang Kuala

\begin{tabular}{|c|c|c|c|c|c|}
\hline \multirow{2}{*}{ No. } & \multirow{2}{*}{ Parameter } & \multirow{2}{*}{ Satuan } & \multicolumn{3}{|c|}{ Lokasi Sampling } \\
\hline & & & T1 & T2 & T3 \\
\hline \multicolumn{6}{|c|}{ Fisik } \\
\hline 1 & Suhu & ${ }^{\circ} \mathrm{C}$ & 30,8 & 31,2 & 29,7 \\
\hline 2 & Salinitas & $\%$ & 23,6 & 22,1 & 21,8 \\
\hline 3 & TDS & $\mathrm{mg} / \mathrm{l}$ & 24,36 & 20,96 & 18,11 \\
\hline \multicolumn{6}{|c|}{ Kimia } \\
\hline 4 & $\mathrm{Ph}$ & - & 5,1 & 5,1 & 5,0 \\
\hline 5 & DO & $\mathrm{mg} / \mathrm{l}$ & 4,06 & 5,13 & 3,75 \\
\hline 6 & $\mathrm{NH}_{3}-\mathrm{N}$ & $\mathrm{mg} / \mathrm{l}$ & 0,14 & 0,39 & 0,20 \\
\hline 7 & $\mathrm{NO}_{2}-\mathrm{N}$ & $\mathrm{mg} / \mathrm{l}$ & 0,04 & 0,05 & 0,05 \\
\hline 8 & $\mathrm{NO}_{3}-\mathrm{N}$ & $\mathrm{mg} / \mathrm{l}$ & 0,23 & 0,24 & 0,27 \\
\hline \multirow{2}{*}{\multicolumn{6}{|c|}{$\begin{array}{l}\text { Keterangan: } \\
\mathrm{T} 1=\text { Tambak Bontang Kuala in let }\end{array}$}} \\
\hline & & & & & \\
\hline \multicolumn{6}{|c|}{ T2 = Tambak Bontang Kuala Tengah } \\
\hline T3 $=$ & ambak Bonta & g Kuala o & & & \\
\hline
\end{tabular}

\section{Suhu Air}

Hasil pengukuran suhu air pada lokasi pengambilan sampel pada tambak di Bontang Kuala, yaitu berkisar antara 29,7 - 31,2 ${ }^{\circ} \mathrm{C}$. Hasil yang diperoleh menunjukkan bahwa fluktuasi suhu air pada pertambakan di Bontang antar lokasi sampling tidak besar (deviasi suhu $\leq 2^{\circ} \mathrm{C}$ ) atau lokasi sampling tidak memperlihatkan perbedaan suhu yang terlalu menyolok $\left( \pm 3^{\circ} \mathrm{C}\right)$.

\section{Salinitas}

Salinitas adalah ukuran jumlah garam yang terlarut di dalam air. Berdasarkan parameter sifat fisik yang terukur (Tabel 1) salinitas air tambak berkisar antara 21,81 - 23,6 $\%$. Hasil ini termasuk dalam kategori salinitas yang layak untuk tambak. Secara umum 
jenis Crustacea tidak sensitif terhadap perubahan salinitas hingga $5 \%$ (Malone dan Burden,1988), Seperti udang mampu hidup dengan baik pada kisaran salinitas $0,5-40 \%$.

\section{Konsentasi Padatan Terlarutnya (TDS)}

Konsentrasi TDS ini sebagian besar berasal dari bahan-bahan terlarut yang ada dalam perairan berupa bahan-bahan dari dalam (autotochnous) ditambah bahan-bahan terlarut dari luar (allotochnous) yang dibawa oleh aliran air limpasan (run-off) yang masuk atau melalui proses degradasi pelarutan bahan-bahan tersebut dari sistem daratan di sekitar daerah aliran. Hasil analisis konsentrasi padatan terlarutnya (TDS) berkisar antara 18,11 - 24,36 mg/l. Nilai ambang batas konsentrasi TDS yang diinginkan dalam air sesuai dengan baku mutu untuk kepentingan perikanan adalah 1000 mg/l, ini berarti bahwa konsentrasi TDS pada pertambakan di Bontang masih di bawah ambang batas yang ditetapkan.

\section{Derajat Kemasaman (pH)}

Nilai $\mathrm{pH}$ adalah nilai dari hasil pengukuran ion hidrogen $\left(\mathrm{H}^{+}\right)$di dalam air. Air dengan kandungan ion $\mathrm{H}^{+}$banyak akan bersifat asam, dan sebaliknya akan bersifat basa (Alkali). Hasil pengukuran derajat kemasaman pada pertambakan di Bontang diperoleh kisaran $\mathrm{pH}$ $5,0-5,1$ selama periode pengamatan. Nilai ini jika mengacu pada kriteria mutu air masih lebih kecil berada pada kisaran derajat kemasaman $(\mathrm{pH})$ yang diinginkan, yaitu $6-9$. Udang toleran terhadap $\mathrm{pH}$ antara $7,0-9,0$. Nilai $\mathrm{pH}$ asam kurang dari 6,5 dan $\mathrm{pH}$ lebih dari 10 berbahaya bagi insang udang dan pertumbuhan terhambat (Van Wyk dan Scarpa, 1999).

\section{Oksigen Terlarut}

Berdasarkan hasil pengukuran konsentrasi oksigen terlarut pada pertambakan di Bontang didapatkan kisaran sebesar 3,75 - 5,13 mg/L. Secara umum dapat dikatakan bahwa konsentrasi oksigen terlarut pada pertambakan tersebut selama periode pengamatan dilaksanakan masih berada dalam ambang batas yang diperbolehkan (kriteria mutu air untuk oksigen terlarut $\geq 3 \mathrm{mg} / \mathrm{L}$ ). Idealnya, konsentrasi oksigen terlarut tidak boleh kurang dari 1,7 ppm selama waktu 8 jam dengan sedikitnya pada tingkat kejenuhan sebesar 70 \% (Huet, 1970). Selanjutnya, Swingle (1968) menjelaskan bahwa konsentrasi oksigen terlarut $\left(\mathrm{O}_{2}\right)$ minimum adalah $2 \mathrm{ppm}$ dalam keadaan nornal dan tidak tercemar oleh senyawa beracun (toksik).

\section{Ammonia}

Pada umumnya konsentrasi ammonia pertambakan di Bontang relatif masih rendah, karena berdasarkan hasil pengukuran pada lokasi sampling pengamatan diperoleh kisaran nilai yang masih berada dalam ambang batas yang ditetapkan jika mengacu pada Baku Mutu untuk Biota laut, yaitu 0,3 - $1 \mathrm{mg} / \mathrm{l}$. Adapun hasil pengukuran ammonia pertambakan di Bontang diperoleh kisaran nilai 0,140-0,390 mg/l. Pada udang, ammonia 
harus kurang dari 0,003 ppm dan akan menimbulkan kematian pada konsentrasi lebih dari 0.1 ppm (Van Wyk dan Scarpa, 1999).

\section{Nitrit dan Nitrat}

Nitrit dan nitrat ada di dalam air sebagai hasil dari oksidasi. Nitrit merupakan hasil oksidasi dari ammonia dengan bantuan bakteri Nitrisomonas dan nitrat hasil dari oksidasi nitrit dengan bantuan bakteri Nitrobacter. Keduanya selalu ada dalam konsentrasi yang rendah, karena tidak stabil akibat proses oksidasi dan sangat tergantung pada keberadaan bahan yang dioksidasi dan bakteri. Kedua bakteri tersebut akan optimal melakukan proses nitrifikasi pada pH 7,0 - 7,3 (Malone dan Burden, 1988).

Berdasarkan hasil pengukuran nitrit pada pertambakan di Bontang diperoleh kisaran nilai antara 0,04-0,05 $\mathrm{mg} / \mathrm{l}$. Besarnya konsentrasi untuk keperluan perikanan (kehidupan biota laut) belum tercantum dalam baku mutu, sehingga kelayakan perairan Bontang untuk kehidupan biota laut berdasarkan konsentrasi nitrit tidak dapat ditentukan. Akan tetapi menurut Van Wyk dan Scarpa (1999), konsentrasi nitrit untuk amannya harus dipertahankan pada level $1 \mathrm{mg} / \mathrm{L}$. Udang jenis monodon lebih tahan terhadap racun nitrit dibanding jenis Vanamei, selanjutnya daya racun nitrit terhadap kepiting lebih sensitif dibanding jenis udang, terutama jenis Vanamei (Van Wyk dan Scarpa, 1999).

Adapun hasil pengukuran nitrat pada pertambakan di Bontang diperoleh kisaran nilai $0,23-0,27 \mathrm{mg} / \mathrm{l}$. Nilai ambang batas konsentrasi nitrat yang diperbolehkan terdapat dalam air laut untuk kehidupan biota laut belum ditetapkan, sehingga peruntukan perairan Bontang bagi keperluan perikanan (kehidupan biota laut) belum dapat dibandingkan.

Van Wyk dan Scarpa (1999) menjelaskan bahnwa nilai konsentrasi nitrat maksimum terhadap yang dibolehkan untuk budidaya adalah 60 ppm untuk jenis udang. Akan tetapi, udang bisa hidup pada konsentrasi nitrat hingga 200 ppm Ketika air mengandung banyak oksigen, tidak akan berbahaya terjadinya denitrifikasi, sehingga konsentrasi nitrat tidak terlalu penting untuk dimonitoring.

\section{Plankton}

Hasil pengamatan terhadap plankton pada tambak di Bontang Kuala dengan melihat komposisi jenis dan perhitungan kelimpahan, indeks keanekaragaman $\left(\mathrm{H}^{\prime}\right)$, indeks keseragaman (E') serta indeks dominan (D'), dapat dilihat pada Tabel 2. Indeks keanekaragaman plankton yang terdapat pada pertambakan di Bontang berkisar antara $1,55-1,88$. Nilai tersebut menunjukkan bahwa keanekaragaman jenis plankton dalam kategori sedang. Nilai keanekaragaman $1<\mathrm{H}^{\prime}<3$; artinya keanekaragaman sedang, penyebaran sedang, kestabilan komunitas sedang. Berdasarkan kriteria dari indeks keanekaragaman ( $\left.H^{\prime}\right)$ (Basmi, 2000), secara umum semua stasiun sampling memiliki keanekaragaman spesies yang tergolong sedang $\left(H^{\prime}: 1-3\right)$ dimana stabilitas komunitas biota termasuk kedalam tingkat moderat, artinya kondisi komunitas di semua lokasi 
sampling mudah berubah hanya dengan mengalami pengaruh lingkungan yang relatif kecil.

Nilai-nilai tersebut menunjukkan bahwa kehidupan antar jenis plankton cukup baik, berimbang, dan tidak ada dominansi. Hal ini terlihat bahwa selama periode penelitian ini, jumlah jenis plankton yang ditemukan pada setiap periode penelitian hanya berkisar 1 - 5 jenis. Nilai indeks keanekaragaman ( $\left.\mathrm{H}^{\prime}\right)$ dikatakan sedang disebabkan karena jumlah jenis dan jumlah individu relatif sedikit.

Tabel 2. Jenis, kelimpahan dan indeks keanekaragaman ( $\left.H^{\prime}\right)$, indeks keseragaman ( $\left.E^{\prime}\right)$ serta indeks dominan (D') plankton pertambakan di Bontang Kuala

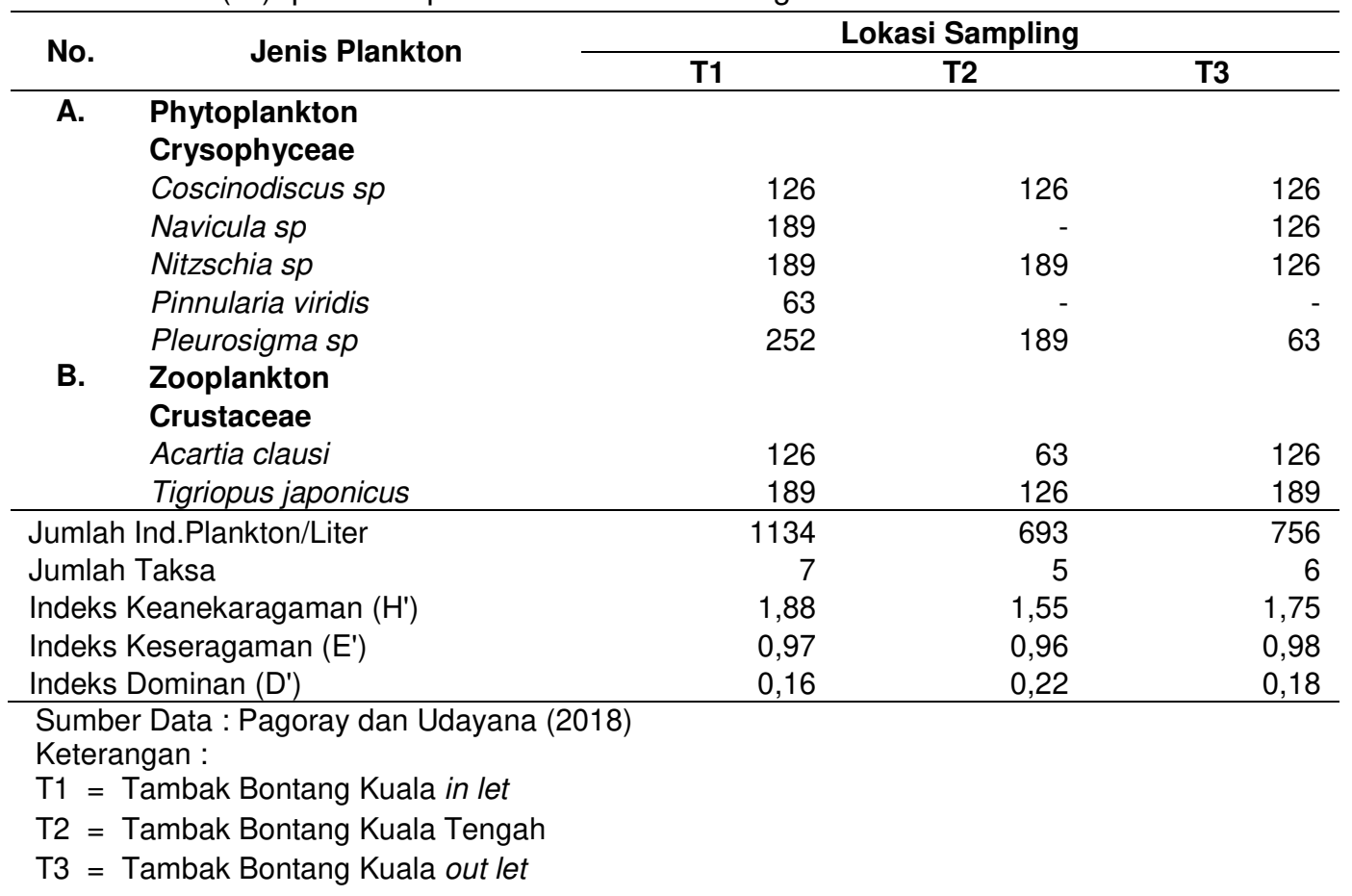

\section{Sifat Fisik dan Kimia Tanah}

Tanah merupakan habitat dari berbagai macam organisme hidup, termasuk biota perairan yang dipeliharan dalam tambak. Kondisi dasar tambak dapat berubah setiap waktu yang dipengaruhi oleh akumulasi residu bahan organik yang semakin meningkat seperti, ganggang yang mati, feses dan residu makanan yang menyebabkan tingginya konsumsi oksigen dan kurangnya tingkat pertumbuhan (Avnimelech et al., 2003). Hasil analisis tanah pada tambak yang digunakan sebagai lokasi sampling di Bontang Kuala berupa parameter $\mathrm{pH}$, bahan organik ( $\mathrm{C}$ total), $\mathrm{N}$ total dan $\mathrm{P}$ total, tekstur tanah tambak.

\section{pH Tanah}

$\mathrm{pH}$ tanah merupakan sifat kimia tanah yang penting bagi tambak, baik untuk budidaya ikan, kepeting dan udang. Sebaliknya $\mathrm{pH}$ tanah dipengaruhi oleh berbagai faktor lain seperti kandungan karbonat bebas (Boyd, et al. 2002), umur tambak dan tanah asli tambak (Avnimelech, et al. 2004). Hasil pengukuran pH tanah tambak pada lokasi pengambilan sampel berada pada kisaran $\mathrm{pH} 6,58-6,82$. $\mathrm{pH}$ tanah yang baik untuk 
budidaya tambak berkisar antara 6,5 - 7,5 sedangkan $\mathrm{pH}$ asam ( $<5$ tidak dianjurkan untuk budidaya di tambak).

\section{Organik (Bahan Organik)}

Bahan organik tanah berperan penting dalam menunjang kesuburan tanah. Tanah dasar tambak asli kebanyakan mempunyai kandungan bahan organik $<2 \%$, sedangkan sedimen biasanya mengandung bahan organik sebesar $3-4 \%$, bahkan tambak yang berumur 50 tahun, kandungan bahan organiknya mencapai 5-6\% (Boyd dan J. Queiroze, 1999). Tanah yang berasal dari endapan di daerah mangove cenderung mempunyai kandungan bahan organik tinggi, sedangkan konsentrasi optimum yang dianjurkan adalah $1-3 \%$ (Boyd, et al. 2002).

Hasil analisis kandungan bahan organik pada lokasi sampling yaitu berada pada kisaran 5,93 \%, hasil ini termasuk dalam kategori tinggi. Karbon organik > 2,5\% menunjukkan kandungan bahan organik tinggi, tidak cocok untuk tambak ikan/udang, mikroba berlebih, oksigen defisit; Karbon organik 1,5-2.5\% menunjukan kandungan bahan organik sedang, tanah produktif. Karbon organik < 0,5\% menunjukan kandungan bahan organik kurang, tanah tidak produktif.

Bahan organik pada lapisan yang lebih dalam dan tanah dasar tambak umumnya lebih tua dan sebagian sudah terdekomposisi, sehingga bahan organik di lapisan ini akan terurai lebih lambat (Boyd dan Queiroze, 1999).

\section{Nutrisi Tanah Tambak (N dan P)}

Nutrisi tambak memberikan pengaruh terhadap kualitas dari tanah tambak karena akan sangat berpengaruh terhadap kesuburan dari tambak. Nutrisi memberikan pengaruh terhadap pertumbuhan dari pakan alami (phytoplankton). Nutrisi tanah tambak yang penting yaitu $\mathrm{N}$ total, $\mathrm{P}$ total dan $\mathrm{K}$ total. Tiga unsur nutrisi penting yang dibutuhkan di tambak budidaya adalah (Boyd, et al 2002) dan (Adhikari, 2003).

Hasil pengukuran $\mathrm{N}$ total pada lokasi pengambilan sampel yaitu berada pada kisaran $0,85 \%$ atau 850 ppm., nilai ini termasuk dalam kategori tinggi. Status kesuburan tanah tambak terhadap Jenis nutrisi tanah Nitrogen memperlihatkan bahwa tambak dengan konsentrasi Nitrogen < 250 ppm mempunyai produktivitas rendah, konsentrasi Nitrogen 250-500 ppm mempunyai Produktivitas sedang, dan konsentrasi Nitrogen $>500$ ppm mempunyai Produktivitas tinggi (Boyd et al., 2002).

Hasil analisis kandungan P-Total pada lokasi sampling yaitu pada tambak di Bontang Kuala berkisar 805 - 910 ppm. Berdasarkan hasil pengukuran P- Total menunjukkan bahwa tambak di Bontang Kuala termasuk kategori produktivitas tinggi. Status kesuburan tanah tambak terhadap Jenis nutrisi tanah Phosfor memperlihatkan bahwa tambak dengan konsentrasi Phosfor < 30 ppm mempunyai produktivitas yang kurang, konsentrasi Phosfor 30-60 ppm mempunyai produktivitas rata-rata, konsentrasi 
Phosfor 60-120 ppm mempunyai produktivitas baik, dan konsentrasi Phosfor > 120 ppm mempunyai produktivitas tinggi (Boyd et al., 2002).

\section{Kesimpulan}

Berdasarkan hasil analisis pada tambak sampling (Bontang Kuala) maka dapat disimpulkan bahwa secara umum kesuburan tambak dilihat dari kualitas air masih memenuhi syarat untuk mendukung kehidupan biota air atau digunakan untuk kepentingan perikanan, sehingga tambak tersebut masih cukup baik dimanfaatkan untuk pemeliharaan (budidaya) udang. Hasil analisis kualitas tanah khususnya bahan organik cukup tinggi. Perlu dilakukan pengelolaan tambak yang lebih intensif, dengan melakukan pengelolaan, pemantauan dan sosialisasi budidaya di tambak.

\section{Daftar Pustaka}

Adhikari, S. (2003). Fertilization, Soil dan Water Quality Management in Small-Scale Ponds: Fertilization Requirementa and soil properties. Central Institute of Freshwater Quaculture, Kausalyagangga, Bulaneswar India. J.Aquaculture Asia, Vol. 7(4).

Avnimelech,Y., G. Ritvo, \& M. Kochva. (2004). evaluating the active redox and organic fractions in pond bottom soils : EOM, eassily oxidized material. Aquaculture 233, 283-292

Basmi, J. (2000). Planktonologi : Plankton sebagai Bioindikator Kualitas Perairan. Fakultas Perikanan dan IImu Kelautan, Institut Pertanian Bogor.

Boyd C.E. \& J. Queiroze. (1999). Pond Soil Characteristics and Dynamics Of Soil Organik Matter and Nutrients. Annual Technical Report. Pond Dynamics/Aquaculture CRSP, Oregon State University, Corvallis, Oregon.

Boyd, C.E., Wood, C.W., \& T. Thunjai. (2002). Pond Soil Characteristics and Dynamics Of Soil Organik Matter and Nutrients. In : K. McElwee, K.Lewis, M. Nidiffer, and P Buitrago (Edition), Ninetenth Annual Technical Report. Pond Dynamics/Aquaculture CRSP, Oregon State University, Corvallis, Oregon.

Effendi, H. (2000). Telaahan Kualitas Air. Bagi Pengelolaan Sumberdaya dan Lingkungan Perairan. Jurusan Manajemen Sumberdaya Perairan. Fakultas Perikanan dan IImu Kelautan Institut Pertanian Bogor. IPB Bogor.

Hermanto. (2007). Pengelolaan Budidaya Tambak Berwawasan Lingkungan. http://ikan mania.Wordpress.com.

Huet, H. B. N. (1970). Water Quality Criteria For Fish Life Bioiogical Problems In Water Pollution. Phs. Publ. No. 999-Wp-25. 160-167 pp.

Malone, R. F. \& D. G. Burden. (1988). Design of Recilculating Blue Crab Shedding System. Louisiana Sea Grant College Program. Louisiana State University. Louisiana. 76 h.

Musa, M. (2004). Kondisi Kualitas Air Pada Budidaya Campuran Ikan Bandeng dan Udang di Tambak Garam Sumenep Madura. Jurnal Penelitian Perikanan Vol. 7(1).

Pagoray H., \& Deni Udayana, (2018). Analisis Kualitas Plankton dan Benthos Tambak Bontang Kuala Kota Bontang Kalimantan Timur. Jurnal Pertanian Terpadu. , Vol. $6(1): 30-38$. 
Swingle, H.S. (1968). Standardization Of Chemical Analysis For Water And Pond Muds. F.A.O. Fish, Rep. 44(4):379 - 406.

Van Wyk, P. \& J. Scarpa. (1999). Water Quality Requirements and Management. Chapter 8 In Farming Marine Shrimp in Recirculating Freshwater Systems. Prepared by Peter Van Wyk, Megan Davis-Hodgkins, Rolland Laramore, Kevan L. Main, Joe Mountain, John Scarpa. Florida Department of Agriculture and Consumers Services. Harbor Branch Oceanographic Institution. 